\title{
Vuoden 1960 väestölaskennan suunnitelmista
}

Fil. maist. JORMA HYPPÖLA

Tilastollinen päätoimisto

Seuraava väestölaskenta suoritetaan Tilastollisen päätoimiston toimesta vuodenvaihteessa 1960/61. Se käsittää maan koko väestön, noin 4500000 henkilöä. Laskennan yhteydessä toimeenpannaan myös asuntojen ja kiinteistöjen inventointi, jonka piiriin kuuluu noin 1500000 rakennusta ja 1300000 asuinhuoneistoa.

Laskennan esityöt. Päätoimiston apuna laskentaa suunniteltaessa on ollut Tilastollisen neuvottelukunnan vuoden 1958 alussa asettama väestölaskentajaosto, jonka puheenjohtajana on toiminut ylijohtaja Valter Lindberg. Väestölaskentajaoston suosituksesta toimeenpantiin 7 kunnan alueella koelaskenta vuoden 1959 henkikirjoituksen yhteydessä. Kaksi maalaiskuntaa laskettiin kokonaan ja kahdesta kaupunkikunnasta, yhdestä kauppalasta ja kahdesta maalaiskunnasta noin 2000 henkeä käsittävät alueet. Käytetyistä lomakkeista pyydettiin myös useiden viranomaisten ja järjestöjen lausunnot. Laskennan myöhempi suunnittelu tapahtui koelaskennan antamien kokemusten sekä saatujen lausuntojen perusteella.

Laskennan organisaatio. Jo vuoden 1953 tilastokomitea suositteli antamassaan mietinnössä, että väestölaskenta-aineiston keräys olisi pyrittävä toimeenpanemaan henkikirjoitusorganisaatiota hyväksi käyttäen (Komiteanmietintö 6/1956, s. 34). Laskennan suunnittelussa onkin tähän kysymykseen kiinnitetty suurta huomiota. On pyritty järjestelmään, jossa vältyttäisiin luomasta laajaa tilapäistä ja kalliiksi tulevaa laskijaverkostoa. Laskentalomakkeiden jako ja keräys tapahtuu henkikirjoitusilmoituslomakkeiden jaon ja keräyksen yhteydessä. Erityisiä laskijoita ei täten tarvita, koska henkikirjoitusviranomaiset, so. maalaiskunnissa henkikirjoituksen piirimiehet ja kaupungeissa ja kauppaloissa poliisilaitokset ja henkikirjoitustoimistot, suorittavat väestölaskentalomakkeiden jaon ja keräyksen. Henkikirjoitusviranomaisten tulee myös tarkistaa, että kaikista niistä henkilöistä ja kiinteistöistä, joista on annettu henkikirjoitusilmoitukset, on annettu myös tiedot väestölaskentaa varten. Väestölaskenta-aineiston a s i a ll in e n tarkastus sen sijaan jää jokaiseen kuntaan asetettavan väestölaskentatoimikunnan tehtäväksi. Tämän toimikunnan tulee myös suorittaa tarpeelliset jälkitiedustelut. 
Niiden uudistusten tultua toteutetuiksi, joita Väestökirjanpitokomitea on esittänyt, voitaneen seuraavissa väestölaskennoissa laskentatoimikuntien tehtävät antaa komitean perustettaviksi ehdottamille rekisterituomareille (Komiteanmietintö 9/1958).

Kyselylomakkeet. Lomakkeita tulee olemaan kahta lajia, ruokakuntaja asuntolomake A sekä kiinteistölomake B. Edellisen täyttää jokainen ruokakunnan päämies, jälkimmäisen kiinteistön omistaja tai hänen edustajansa. Asuinhuoneistoja koskevat tiedot kerätään A-lomakkeella ja ne antaa huoneiston haltija. A-lomakkeet luovutetaan kiinteistön omistajalle tai isännöitsijälle, joka toimittaa ne henkikirjoitusilmoitusten kanssa edelleen henkikirjoitusviranomaisille. Lomakkeet ovat kaksikielisiä, puhtaasti suomenkielisissä kunnissa kuitenkin vain suomenkielisiä.

Vuoden 1950 väestölaskennan $\mathrm{ru} \mathrm{ok} \mathrm{a} \mathrm{k} \mathrm{unta-} \mathrm{ja} \mathrm{a} \mathrm{s} \mathrm{u} \mathrm{n} \mathrm{to} \mathrm{lo} \mathrm{make}$ oli varsin laaja. Tulokset osoittivat, että eräisiin kysymyksiin annetut vastaukset olivat puutteellisia, vaikka laskijoille oli annettu tehtäväksi tarpeen vaatiessa avustaa lomakkeiden täyttämistä. Vuoden 1950 väestölaskennan sekä viime vuoden alussa toimeenpannun koelaskennan antamien kokemusten perusteella päätettiin luopua eräistä kysymyksistä, jotka sisältyivät edelliseen laskentaan. Samalla on lomakkeen muotoa pyritty yksinkertaistamaan.

Ruokakunta- ja asuntolomakkeen henkilö-osan kysymykset ovat seuraavat:

Nimi

Asema ruokakunnassa

Sukupuoli

Siviilisääty

Seurakunta tai siviilirekisteri

Syntymävuosi

Syntymäpaikka

Kansalaisuus

Pääkieli

Yleissivistys (keskikoulukurssi, ylioppilastutkinto)

Ammatillinen koulutus

Pääammatti, -toimi tai -toiminta

Ammattiasema

Yrityksen tai työnantajan nimi ja osoite

Työpaikan laatu

Peltoala

Avustavia perheenjäseniä koskeva kysymys

Metsä- ja uittotöissä oloa koskeva kysymys

Onko yrityksessä palkattuja työntekijöitä

Siirtoväkeen kuuluneen vakinainen asuinpaikka syyskuun 1 p:nä 1939

Viimeksimainittu kysymys koskee vain niitä henkilöitä, jotka 1. 9. 1939 asuivat sittemmin Neuvostoliitolle luovutetulla tai vuokratulla alueella.

Ehkä tärkeimmät vuoden 1950 väestölaskentaan sisältyneet, mutta uudesta laskennasta koelaskennan antamien kokemusten perusteella pois jätetyt kysymykset koskivat sivuammattia sekä naimisissa olevien naisten avioliiton solmimisvuotta ja tässä avioliitossa syntyneiden lasten lukumäärää. 
Lomakkeen a suin hu on e is toja koskevat kysymykset ovat suunnilleen samat kuin vuonna 1950. Lisäksi on tällä kertaa tarkoitus kerätä tietoja myös asuinhuoneistojen pinta-aloista. Useiden viranomaisten ja järjestöjen lausunnoissa korostettiin näiden tietojen tärkeyttä. On kuitenkin pelättävissä, että vastausten saanti tähän kysymykseen tulee tuottamaan suuria vaikeuksia, varsinkin maaseudulla.

Lomake sisältää seuraavat kohdat:

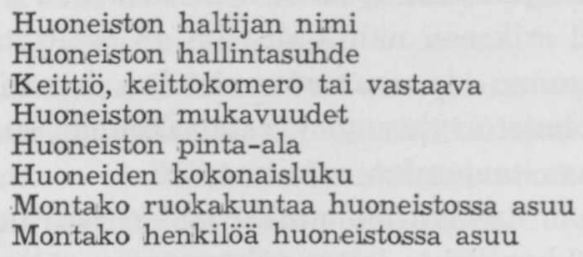

Edellä olevan lisäksi kysytään ruokakunnan käytössä olevien huoneiden lukumäärää sekä, onko joku ruokakunnan jäsenistä huoneiston haltija vai ei. Nämä esitetään kaikkien ruokakuntien, siis myös alivuokralaisina asuvien, vastattaviksi.

$\mathrm{K}$ i inte istölomak ke en kysymykset kohdistuvat rakennettuihin kiinteistöihin. Laskennan ulkopuolelle jäävät kuitenkin yksinomaan kesäkäyttöä varten rakennetut huvilat, koska tietojen saanti näistä on osoittautunut käytännöllisesti katsoen mahdottomaksi. Yksinomaan maataloustuotantotarkoituksiin käytetyt rakennukset eivät myöskään sisälly laskennan piiriin. Jälkimmäinen rajoitus on tehty yhteisymmärryksessä Maataloustilastotoimikunnan kanssa.

Koelaskennassa pyrittiin saamaan tietoja rakennusten tilavuudesta. Annetut vastaukset olivat kuitenkin siksi puutteellisia, että kysymyksestä jouduttiin luopumaan. Sen sijaan on tarkoitus kerätä tiedot myymälä-, konttori-, tehdas-, laitos-, kokous-, yms. huoneistotiloista. Tämän tiedustelun tärkeyttä on korostettava lähinnä yhdyskuntasuunnittelun kannalta. Oikeiden vastausten saanti tähän kohtaan tulee todennäköisesti olemaan helpompi kuin edelliseen, koska tiedonantajien piiri on huomattavasti suppeampi ja sellaisten talojen omistajat ja isännöitsijät, joissa mainittuja huoneistoja sijaitsee, ovat tottuneempia tietojen antamiseen.

Kiinteistöjen nimen ja rakennusten omistajan lisäksi kerätään kiinteistöjen osalta myös eräitä identifiointitietoja.

Rakennuksia koskevat kysymykset ovat seuraavat:

Rakennuksen käyttötarkoitus

Minä vuonna rakennus on valmistunut käyttökuntoon

Rakennusaine

Lämmitystapa

Asuinhuoneistojen luku

Saunojen luku

Kerrosluku 
Kiinteistölomakkeen kääntöpuolella olevassa taulukossa pyydetään seuraavia tietoja myymälä-, konttori-, tehdas-, laitos-, kokous-, yms. huoneistoista:

Huoneiston käyttö

Huoneiden lukumäärä

Huoneiston pinta-ala

Taajamat. Useiden maalaiskuntien alueelle on syntynyt asutuksen tihentymiä, taajamia, jotka luonteensa puolesta eroavat huomattavasti puhtaasta maaseudusta. Tietojen saanti erikseen näiltä alueilta on osoittautunut erittäin tärkeäksi mm. valtakunnan- ja seutusuunnittelun kannalta. Tämän vuoksi on Tilastollinen päätoimisto ryhtynyt väestölaskennan suunnittelutöiden yhteydessä suorittamaan taajamien rajoitustyötä.

Pohjoismaisen suosituksen mukaan luetaan taajamiksi kaikki ne rakennusryhmät, joissa asuu vähintäin 200 henkeä ja joissa rakennusten välimatkat eivät yleensä ole 200 metriä suuremmat. Tästä perusmääritelmästä sallitaan kuitenkin eräitä poikkeuksia. Taajamien rajoittaminen suoritetaan kartalle käyttäen hyväksi Maanmittaushallituksen ilmavalokuvatoimistosta lainattuja ilmakuvakarttoja ja niiden puuttuessa ilmavalokuvia. Maalaiskuntien alueella olevien taajamien lukumäärä on n. 1400.

Ruutumenetelmä. Koelaskennan yhteydessä kokeiltiin peruskartan ruuduston käyttöä tilastojen alueellisena jaotuksena Eräjärven ja Sipoon kunnissa (Hyppölä 1959). Edellisessä kunnassa valittiin ruudun sivun pituudeksi $1 \mathrm{~km}$ ja jälkimmäisessä $0.5 \mathrm{~km}$. Tällainen menetelmä tarjoaa mahdollisuuden saada tiedot pieniin alueisiin kohdistuvina. Ruutumenetelmää on tarkoitus soveltaa vain suurimpien kaupunkien vaikutusalueilla, missä tarve saada tietoja pieniltä maantieteellisiltä alueilta on suurin. Menetelmän soveltaminen tapahtuu siten, että väestölaskentalomakkeiden kerääjä (henkikirjoituksen piirimies) kirjoittaa kuhunkin lomakkeeseen sen karttaruudun koordinaattinumerot, johon asianomainen ruokakunta tai kiinteistö kuuluu.

Konekäyttely. Ruotsin Tilastollinen päätoimisto on tilannut konekeskukseensa lähinnä väestölaskenta-aineiston käyttelyä varten elektronitietokoneen IBM 7070. Koska tällainen kone suuresti nopeuttaa aineiston käyttelyä ja alentaa kustannuksia, on Ruotsin päätoimiston kanssa sovittu siitä, että myös Suomen väestölaskennan aineisto käytellään tällä koneella. Reikäkortit lävistetään ja tarkistetaan Suomessa, minkä jälkeen tiedot siirretään magneettinauhoille, jotka lähetetään Ruotsiin siellä elektronikoneella käyteltäviksi. Alustavan työsuunnitelman mukaan saadaan laskennan tulokset Ruotsista konetauluina syksyllä 1962, minkä jälkeen seuraa työtaulujen ja julkaisujen laatiminen.

Ryhmitykset. Elinkeinoryhmitys perustuu Yhdistyneiden Kansakuntien tilastokomitean laatimaan ja suosittelemaan uusittuun elinkeinoluokitteluun (United Nations 1958). Vain vähäisiä muutoksia on jouduttu suorittamaan vuoden 1950 ryhmittelyyn nähden. 
Ammattiryhmittelyssä otetaan käytäntöön pohjoismainen suositus ammattien luokitteluksi (3-numeroinen tunnus). Tämä puolestaan perustuu Kansainvälisen työtoimiston (ILO) laatiman ja Yhdistyneiden Kansakuntien suositteleman ehdotuksen pohjalle (International Labour Office 1958). Uusi ammattiryhmitys eroaa huomattavasti edellisen väestölaskennan vastaavasta ryhmityksestä, jota laadittaessa oli käytettävänä vain yksinumeroinen kansainvälinen suositus.

A mmattiasemaryhmitys tulee olemaan sama kuin vuoden 1950 väestölaskennassa.

Ammattikoulutusryhmitys joudutaan huomattavilta osin uusimaan. Koska yhtenäisten tietojen saanti lyhytaikaisista ammattikursseista on osoittautunut mahdottomaksi, jätetään tällä kertaa alle 6 kk. kestävät kurssit huomioon ottamatta.

Uutena ryhmityksenä on mainittava YK:n tilastotoimiston suosittelema sosia a liry hmitys, joka perustuu Euroopan tilastokongressin laatimaan ehdotukseen. Käytettävä sosiaaliryhmitys käsittää 16 ryhmää.

Tutkimus, joka koskee ty öpaikan sijaintia asuinkunnan ulkopuolella, on tarkoitus ulottaa käsittämään laajemmat alueet kuin v. 1950. Tutkimusalueiden määritteleminen suoritetaan yhteistoiminnassa Valtakunnansuunnittelutoimiston ja makunnallisten seutusuunnitteluelimien kanssa.

Siirtoväen Nyky-Suomeen sijoittumisen selvittämiseksi on otettu kysymys asuinpaikasta 1. 9. 1939. Tämä kysymys esitetään niille, jotka mainittuna ajankohtana asuivat sittemmin Neuvostoliitolle luovutetulla tai vuokratulla alueella.

Taulusuunnitelmia laadittaessa on kiinnitetty entistä suurempaa huomiota siihen, että tärkeimmät tiedot saataisiin erikseen pienimmistä maantieteellisistä alueista, so. kunnittain ja taajamittain sekä kolmessa suurimmassa kaupungissa kaupunginosittain. Läänitietojen lisäksi on katsottu tarpeelliseksi laatia useat taulut myös talousalueittain (Sahavirta 1958). Tämän uuden aluejaon käyttö on tullut yhä yleisemmäksi varsinkin suunnittelu- ja tutkimustyössä.

Henkilötilastossa saadaan kunta-, taajama- tai kaupunginosakohtaiset tiedot asukasluvusta ja asukkaiden jakautumisesta kielen, koulusivistyksen, iän, sukupuolen, elinkeinon ja ammattiaseman mukaan. Pääkieleltään ruotsinkielisestä väestöstä laaditaan tilasto iän, sukupuolen, elinkeinon ja ammattiaseman mukaan. Eri ominaisuuksien kombinaatioista mainittakoon ikä ja siviilisääty, ikä ja koulusivistys, uskontokunta ja ikä, ikä ja kansalaisuus, elinkeino ja ammattiasema, ammattiasema ja ikä, ammatti ja ikä, ammattikoulutus ja ikä, ammatti ja ammattikoulutus, elinkeino ja työnantaja

Paitsi henkilötilastoa, laaditaan saatavien tietojen perusteella myös perhe- ja ruokakuntatilasto. Perheen muodostavat joko molemmat vanhemmat tai jompikumpi heistä ja heidän (hänen) lapsensa sekä 
lapsettomat aviopuolisot. Perheessä voi olla vain kaksi perättäistä sukupolvea. Ruokakunnan taas muodostavat henkilöt, jotka asuvat yhdessä ja joilla on yhteinen ruokatalous. Perhetilastossa ovat ryhmittelyperusteena perhetyyppi, perheen päämiehen sosiaaliasema ja ikä, perheessä olevien lasten lukumäärä sekä perheenäidin työssä käynti. Ruokakuntatilastossa ruokakunnat ryhmitetään ruokakunnan henkilöluvun sekä päämiehen iän, sukupuolen ja siviilisäädyn mukaan. Näistä vain ruokakunnan suuruutta osoittava taulu on kunta- ja taajamakohtainen.

A suntotilastoss a saadaan tiedot asuinhuoneistoista huoneluvun, huoneiston pinta-alan, huoneiston mukavuuksien sekä huoneiston hallintaperusteen mukaan kunnittain ja taajamittain sekä kolmen suurimman kaupungin osalta kaupunginosittain. Henkilö- ja huoneluku kombinoidaan keskenään. Edelleen on tarkoitus selvittää erikseen huoneistonhaltijaruokakunnat ja alivuokralaisruokakunnat päämiehen sosiaaliaseman, henkilöluvun sekä käytettävissä olevien huoneiden luvun mukaan.

Tärkeimmät rakennuslaskennasta saatavat tiedot on niin ikään aikomus käytellä kunnittain ja taajamittain sekä kolmen suurimman kaupungin osalta kaupunginosittain. Pienimpiin maantieteellisiin alueisiin kohdistuvina saadaan myös tiedot myymälä-, konttori-, tehdas-, laitosyms. huoneistoista, jotka tulevat ryhmiteltäviksi pinta-alan, iän ja huoneiden luvun mukaan. Eri ominaisuuksien kombinoinnista mainittakoon rakentamisvuosi, rakennuksen käyttö ja rakennusaine.

Tilastollisella päätoimistolla ja Tilastollisen neuvottelukunnan väestölaskentajaostolla on ollut vaikea tehtävä pyrkiessään toisaalta ottamaan huomioon tilastotietojen tarvitsijoiden näkökohdat mahdollisimman suuressa määrin ja toisaalta arvioidessaan olemassa olevia käytännöllisiä mahdollisuuksia näiden tietojen hankkimiseksi kustannuksia kohtuuttomasti lisäämättä. Edellä esitetyt suunnitelmat, joihin tosin vielä voi tulla eräitä muutoksia, toivottavasti tyydyttävät mahdollisimman monia väestölaskennan tulosten käyttäjiä.

\section{Kirjallisuus}

Hyppölä, Jorma. Peruskartan ruuduston käyttö tilastojen alueellisena jaotuksena. (Summary: Use of the Squares of the Basic Map as the Smallest Area Division in Statistics.) Tilastokatsauksia 1959, 4, s. 39-43.

International Labour Office. International Standard Classification of Occupations. Geneva 1958.

Komiteanmietintö 6/1956. Suomen yhteiskuntatilasto ja sen kehittäminen. Vuoden 1953 tilastokomitean mietintö. Helsinki 1956.

Komiteanmietintö, 9/1958. Väestökirjanpitokomitean mietintö. Helsinki 1958.

Sahavirta, Aarre. Alueellisen jaotuksen uusiminen tilastoissa. (Summary: Reform of the Geographic Division in Statistics.) Tilastokatsauksia 1958, 12, s. 41-43.

United Nations Statistical Office. International Standard Industrial Classification of All Economic Activities. Statistical Papers, Series M, No. 4 (rev.). New York 1958. 


\title{
Summary:
}

\section{The Plans for the 1960 Population Census in Finland}

\author{
By JORMA HYPPÖLÄ \\ Central Statistical Office of Finland
}

The next population census in Finland will be taken, under the direction of the country's Central Statistical Office, at the turn of 1960. It will include the whole population of the country, i.e. some 4.5 million people. In connection with this census a housing and real-estate census covering some 1.5 million buildings and 1.3 million dwellings will be carried out as well.

The Preliminaries. In planning the census the Central Statistical Office has been assisted by the Subcommittee of Population Census, instituted by the Consultative Statistical Board at the beginning of 1958, upon whose recommendation a pilot census was carried out in seven communes in connection with the 1959 annual population registration. Several authorities and organizations were requested to give their opinions of the questionnaires that had been used. The further planning of the census was based on the experiences gained from the pilot census and on the opinions given.

The Organization of the Census. The census questionnaires will be distributed and collected simultaneously with the population registration forms. Thus no special enumerators are needed, as the registration authorities will also distribute and collect the census questionnaires. The checking of the statements made will be done by a special Census Board to be set up in every commune. This Board has also to make the necessary supplementary inquiries.

The Questionnaires. There will be two kinds of forms: Form A for households and dwellings and Form B for real estates. The former is to be filled out by every head of a household, the latter by the real-estate owner or his representative. The statements about the dwellings - as made by their occupants - it is intended to gather on the forms A. Subsequently, the forms will be handed over to the real-estate owners or managers and forwarded by these together with the registration reports to the population-registration authorities.

The columns for personal data in the form for households and dwellings are mainly of the same type as in 1950. Likewise, the questions relative to the dwellings roughly equal those of that year. This time, however, the plans are to gather information about the areas of the dwellings as well.

The questions in the real-estate form concern the built-up estates. Buildings used exclusively for purposes of agricultural production, on the other hand, are left out of account in this census. Information is also going to be gathered about the premises used for shops, offices, factories, institutions, as meeting rooms, etc.

The Non-administrative Agglomerations. In many rural communes the settlement has here and there concentrated so as to form non-administrative agglomerations, which differ considerably in character from the countryside proper. Obtaining information separately from these areas has proved extremely important with a view to the needs of national and regional planning.

On a joint suggestion made by the central statistical offices in the Northern Countries all groups of buildings occupied by at least 200 people and where the distances between the houses do not generally exceed 200 metres will be regarded - with a few exceptions - as non-2dministrative agglomerations. The number of these agglomerations in the rural communes is about 1400 . 
The Square Method. In connection with the pilot census an experiment was made in the communes of Eräjärvi and Sipoo to use the squares of the basic maps for statistical area division. In the former commune the side of the square chosen was $1 \mathrm{~km}$, in the latter $0.5 \mathrm{~km}$. A method like this offers the possibility of obtaining information about very small areas. It is in fact intended to apply it in the spheres of influence of the largest towns only, where the need to procure information from small georgraphical areas is greatest.

The Processing of the Material. The data to be obtained from the census material will be transferred on punch cards in the Central Statistical Office of Finland whereupon follows a careful revision. After this the data will be recorded on tapes and sent to Stockholm for processing in an IBM 7070 data processing system rented by the Central Statistical Office of Sweden.

The Classifications. In classifying the population by different characteristics the Office will be guided, wherever possible, by the suggestions of the Statistical Office of the United Nations. More attention than before has been paid, in the preparation of plans for the statistical tables, to getting the most important data separately from the smallest geographical areas, i.e. the communes and non-administrative agglomerations as well as the several districts of the three largest towns. Besides for the counties it has proved necessary likewise to make a number of tables for the country's economic areas. 